\title{
TAX AVOIDANCE AS A THREAT TO ECONOMIC SECURITY: WAYS AND METHODS OF COUNTERACTION (DOMESTIC AND FOREIGN EXPERIENCE)
}

\author{
Serhii Minchenko ${ }^{1}$ \\ National Prosecution Academy of Ukraine, Ukraine \\ Olena Oliinyk ${ }^{2}$ \\ Kyiv National Economic University named after Vadym Hetman, Ukraine \\ Andrii Borovyk ${ }^{3}$ \\ Academician Stepan Demianchuk International University of Economics and Humanities, Ukraine
}

\begin{abstract}
The article is devoted to separate issues of the use of criminal law in the regulation and protection of economic relations, as well as the question of the effectiveness of using such a method to ensure the country's economic security. The comparison of methods and methods used in Ukraine, the USA, Germany, Spain, Belarus, which consisted both in the criminalization of certain acts and in the introduction of incentive and incentive rules for taxpayers. The subject of the study is the issue of criminalization and decriminalization of certain social relations in the field of economic security. First of all, it concerns the sphere of payment to the budget of taxes and other mandatory payments. The purpose of the article is to identify the factors that negatively affect the development of the modern economy. Also, the study revealed and analysed the differences in the formulation of laws that provide for liability for tax evasion in order to find out the effectiveness of the latter. Methodology. During the research, a complex of general scientific methods was used: the system - in the process of a comprehensive study of the system of criminal legal influence on the participants of the considered social relations; formally-dogmatic - when analysing the legal composition of crimes involving criminal liability for tax evasion; comparative-legal - within the framework of comparison of provisions of the current Criminal Code of Ukraine and legislation on criminal liability of foreign countries; statistical - for the analysis and generalization of empirical information. Conclusions. Indicates the need for concentration of efforts aimed at carrying out preventive activities in the field of public relations, which, in turn, will contribute to the timely detection and termination of illegal activities, which is a serious threat to the economic security of each civilized country. The general concept for a set of measures that effectively and timely counteract certain socially negative (dangerous) tendencies that should take place today in the sphere of economic relations both in Ukraine and abroad is developed and proposed. The authors expressed their own proposals regarding the improvement of the law on criminal liability for the issue raised.
\end{abstract}

Key words: taxes, fees, compulsory payments, evasion, financial resources, criminalization, fictitious entrepreneurship.

JEL Classification: H23, E42, L26

\section{Introduction}

Issues of state regulation of economic relations by criminalizing certain types of activity, in particular, in the area of taxation, use of financial resources, fictitious entrepreneurship, were considered at different periods by authors such as P.P. Andrushko, V.I. Borisov, L.P. Brich, B.V. Volzhenkin, N.O. Gutorova,
A.O. Dudorov, A.G. Kalman, M.I. Korzhansky, P.S. Matyshevsky, M.I. Melnyk, V.O. Navrotsky, A.I. Perepelitsa, V.M. Popovich, A.V. Savchenko, V.V. Stashis, Y.L. Streltsov, V.Y. Tatsiy, M.I. Khavronyuk, V.P. Khomenko, and others.

The social and political situation in the country points to the need to reconsider the approach both to the criminalization of acts related to tax evasion

\footnotetext{
Corresponding author:

${ }^{1}$ National Prosecution Academy of Ukraine.

${ }^{2}$ Department of Criminal Law and Procedure, Kyiv National Economic University named after Vadym Hetman.

${ }^{3}$ Department of Criminal Law and Justice, Academician Stepan Demianchuk International University of Economics and Humanities.
} 
and to the introduction of a series of encouraging and stimulating norms aimed at the formation of taxpayers' legal consciousness, the creation of such a regime of economics, in which conditions are untimely and the incomplete payment of taxes will be economically less attractive than complying with the requirements of legislation in this area.

However, in spite of the pain and urgency of this issue, the authors mentioned different approaches to resolving these issues, some agreement on the elaboration of a general concept for a set of measures that would effectively and timely counteract the socially negative (dangerous) trends that are supposed to be today in these areas has not been achieved.

Despite the fact that intentional tax evasion and compulsory payments, as well as fictitious entrepreneurship, as a means to achieve this goal, annually cause damage to the state budget more than crime of other categories, criminalization of these acts in the form that exists on this time, as a lever of influence on economic relations was extremely ineffective.

In most cases, fictitious business, consisting in the formation of enterprises whose sole purpose is not the pursuit of economic activity, but the implementation of pseudo-operations, which, as a result of which enterprises in the real sector of the economy reduce their obligations to the budget by assigning a debt to false enterprises - "one-day" which have neither fixed assets nor any other property for foreclosure in order to compensate for the damage to the budget, is a component of tax evasion.

\section{The current situation on the issue in Ukraine}

At present, as a means of tax evasion, fictitious entrepreneurship in Ukraine has become threatened, and the activity of registering fictitious companies, forming the required documents "on request" - has created a separate segment of the economy with a high level of organization and conspiracy.

The abovementioned crimes not only seriously harm the state's economic security due to the negative impact on tax and budget policies, social security, the development of priority sectors of the economy, the maintenance of the army, etc., but is also a significant obstacle to ensuring equal conditions for entrepreneurship and competitiveness, since "minimizers" for the lack of proper response from public authorities, are more competitive and crowded out of the market, which honestly pay taxes.

Such uneven preconditions also reject potential investors, for which compliance with the law is one of the main principles of business organization.

Under such conditions, it is important to introduce an effective mechanism for detecting, stopping unlawful activities for tax evasion, ensuring untaxed funds, bringing in guilty persons, or imposing financial sanctions as a means of preventing similar actions in further activities and equalizing opportunities with honest payers, a means of influencing and regulating economic relations.

The problem of applying the criminal law, which implies a responsibility for tax evasion and false entrepreneurship, is a constant subject of debate among judicial and law enforcement agencies, but measures to improve them are not taken.

Revision of the disposition of Art. 212 of the Criminal Code of Ukraine, for example, has not changed since 2008 but has been supplemented by parts 4 and 5, which contain incentive norms for taxpayers, and the wording of Art. 205 of the Criminal Code of Ukraine, changed in 2011, in our opinion, only complicated the work of fiscal and other law enforcement agencies, directing their efforts to document circumstances that in themselves do not constitute a major public danger and the significant economic effect of their investigation is not achieved. Recognition of a company fictitious is used by the fiscal authorities as a means of pressure on enterprises of the real sector of the economy without achieving an economic effect for the country.

In our opinion, one of the reasons for the ineffectiveness of criminal liability for fictitious entrepreneurship as a lever of influence on economic relations is the imperfect formulation of its disposition, which focuses on identifying and fixing primarily the establishment of such enterprises, and not their activities. The infliction of large pecuniary damage serves only as a qualifying attribute of the offense (On Amendments to the Law of Ukraine regarding humanization of responsibility for offenses in the sphere of economic activity, 2015).

In this case, the necessary mandatory feature of the crime is the presence of a special purpose at the time of the acquisition of the formation of the enterprise a cover of illegal activities.

Moreover, such a goal must be available to the person at the time of the commission of activities for the formation, acquisition of the enterprise. However, in most cases, individuals from among the socially deprived citizens have the sole purpose of obtaining material remuneration for the formal registration of their own enterprises. They are not interested in any further fate of the enterprise, nor for any purpose - legal or illegal - intend to use it by persons who offered and helped to register or re-register the company.

In such circumstances, the intent of the said persons does not cover any specific illegal purpose and it is completely unknown to them what kind of illegal activity is intended to cover those who inclined them to register themselves with the enterprises.

Moreover, the disposition of this article is formulated in such a way that, if at the time of the acquisition or formation of the enterprise the person did not have any 
unlawful purpose, and such a goal appeared after the actions of the formation or acquisition of the enterprise, its actions do not contain signs of the said crime but it is practically impossible to prove the time of occurrence of such a motive.

Not in line with current conditions and trends in the development of social relations in the field of economic activity is the disposition of Art. 212 of the Criminal Code of Ukraine, which is constructed by the legislator as a crime with material composition. In order to find out the presence of features of the crime in the person's actions, it is necessary that certain criminal liability laws be established, the consequences in the form of actual non-availability to the budgets or state target funds of funds in significant (large or especially large) amounts that are in a causal relationship with the actions or inaction of the guilty person.

It should be noted that the scope of taxation in Ukraine is regulated by the following legislative acts: the Constitution of Ukraine, the Tax Code of Ukraine, the Budget Code of Ukraine, the Customs Code of Ukraine, the Code of Merchant Shipping of Ukraine, the Laws of Ukraine: "On Principles of State Regulatory Policy in the Field of Economic Activity”, "On Personal Income Tax", "On Value Added Tax", "On the CMU”, "On the State Fiscal Service of Ukraine" and the number of subordinate normative acts that submit almost daily numerous changes and additions. Such a state of tax law cannot but affects the quality of accounting and education of taxpayers themselves.

\section{Problematic issues regarding the application of legislation providing for criminal liability for tax evasion}

As noted above, the offense under consideration is deemed to be terminated from the moment of actual non-receipt of funds in the budgets or state target funds in significant (large or especially large) amounts. Such non-use is deducted by the state fiscal authorities of Ukraine, which, in accordance with their tasks and authorities, are responsible for implementing the state tax policy and carry out, within the limits of the powers provided for by law, control over the receipt of taxes and duties, customs and other payments, and other state budget funds.

At the same time, the obligatory and the most difficult element to prove the guilt of committing the crime in question is the establishment of the guilty person's intention to avoid paying taxes. In the presence of modern business entities, consultants engaged in accounting and reporting, or structural units in companies whose officials are engaged in these functions, to bring the knowledge of the head of the business entity about the incorrect application of the rules of taxation in the field of taxation, its awareness regarding the intentional actions aimed at tax evasion, is a complicated thing.
As a result, the refutation of the arguments of the fiscal authorities and the prosecution party is based on the fact that the head of the company does not include accounting and tax accounting, taxes and deductions of taxes and duties since such functions have been transferred to other persons. On the other hand, the head of a financial unit or accounting department does not usually handle the entire document flow, since these functions are distributed among subordinate employees, most of which, although they directly carry out all economic transactions, however, are not subjects of the crime envisaged in Art. 212 of the Criminal Code of Ukraine.

Under such conditions, it is impossible to determine directly the managers who are interested in minimizing the tax burden without establishing the facts of the preliminary conspiracy, giving specific instructions from the company managers, forging documents, and directing them directly to the responsible authorities.

In addition, the ambiguity and contradictory nature of the tax legislation, the diversity of the approach to their interpretation, and the constant change in the legal position of the tax authorities became the basis for the Supreme Court's ruling of February 20, 2018, in the case No. $813 / 2617 / 15$, where the court concluded that it was not may be brought to the responsibility of the taxpayer who acted in accordance with the tax advice provided to him in writing or in electronic form, as well as a general tax advice, in particular, on the basis of First, that in the future such generalizing tax advice or tax advice has been changed or cancelled (Art. 53 of the Tax Code of Ukraine).

The lack of a clear legal position on the tax question, the opposite or changing position of tax authorities regarding their application is also an additional opportunity to avoid liability for non-payment of taxes.

As a result, although criminal proceedings are initiated on the facts of evasion from taxes on hundreds of millions of hryvnias, there is virtually no information about the actual convictions of the perpetrators.

A sample of the Unified State Register of Judgments based on the search criteria "sentence", "crimes in the field of economic activity", "tax evasion" for the period from $01 / 01 / 2017$ to $31 / 12 / 2017$ revealed 38 sentences in cases of this category, of which, according to data accounting, as of August 2018, only 21 has become legally binding.

The indicated sentences approved an agreement with the accused in 10 proceedings and sentenced to a fine in the amount of 17 thousand UAH up to 255 thousand $\mathrm{UAH}$, and another 10 people were convicted on the results of proceedings in the normal manner to fines of the same magnitude. Only one person has been ordered by a court of the first instance to pay a fine in excess of 2.5 million UAH.

At the same time, in 6 proceedings, the defendants were released from criminal liability on various grounds and 11 persons were acquitted (Register of judicial decisions of Ukraine). 
The study of persons sentenced for intentional evasion of taxes and the circumstances of a criminal offense revealed a certain tendency: most of them are not managers of the enterprise that evade tax payments, but were executives or founders of business entities with signs of fictitiousness and only contributed to the evasion from paying taxes to heads of other business entities, details of which were not established during the pre-trial investigation.

Cases of prosecution of heads of business entities are singular and more likely to look like an exception to the rule that gives grounds for the conclusion about inefficiencies in the impact on economic relations in the sphere of filling the budgets and protecting the economy by criminal means.

\section{The experience of foreign countries in preventing crimes that adversely affect economic security}

However, there are many successful approaches to protecting the state's economy from "minimizers" by creating conditions for their legitimate behaviour and payment of arrears to the budget and reimbursement of damages.

Here's what offers us successful experience in foreign countries. So, the illustrative example of using the methods of influence on the unscrupulous taxpayer is the case of the Portuguese footballer Cristiano Ronaldo, opened in June 2017, started on the report of the State Tax Agency of Spain. In the case, the tax position was based on the fact that the transfer of non-proprietary rights to the brand was fictitious with the use of offshore companies.

The reason for the decision in favour of the state was the conclusion of the court that the defence "could not provide specific explanations regarding tax operations that led to the commencement of investigations." And this thesis is the basis of the decision to recover 15 million euro in favour of the Spanish budget (https://juscutum. com/futbolisti-vs-podatkivci-ofshorne-merezh/).

It is indicative that the fact of carrying out questionable operations, which resulted in the minimization of the tax burden, was acknowledged as proof of the tendency to avoid tax payments. In the court's opinion, this is evidence of the intentional actions of a person who has benefited from this.

In another case, considered in May 2017, the Spanish Supreme Court ruled that a striker of the Barcelona football club Leonel Messi and his father Jorge Oracio Messi were sentenced to 21 months in prison for tax evasion of 4.1 million euro.

The arguments of the defence that Lionel Messi did not know about his financial affairs and did not suspect any violations of the law when his father gave him documents or contracts for signature, the Supreme Court failed to take into account.
According to the criminal legislation of Ukraine, such actions could not be regarded as intentional, and thus would also be excluded from liability, for example, under the law of Ukraine on criminal liability.

Why, unlike domestic legislation, which in these cases would be "powerless" to prove the fact of tax evasion, the legislation of Spain proved to be effective.

We will analyse the tax evasion wording for the Spanish Criminal Code. In Art. 305 of the Criminal Code of Spain established that criminal responsibility occurs for any action or inaction, which leads to causing losses to the budgets by their failure to pay, debit debt or repossession (Criminal Code of Spain, 1998).

The sanction of the article provides for punishment in the form of deprivation of liberty from one to four years with a fine of six times the amount of assessed sums.

At the same time, the article contains an incentive clause, which provides for exemption from criminal liability, if a person, before being informed of the commencement of a tax audit, or if such an examination has been initiated, but before the prosecutor's office, the state prosecutor or procedural representative of the administration of the autonomy, or the local administration will file a complaint or a statement against that person, or until the Prosecutor's Office or the investigating judge acts in consequence of which the person becomes aware of the initiation of an investigation (Criminal Code of Spain, 2007).

\section{Comparative characteristics of legislation of Ukraine and other countries}

Thus, there are two significant differences in the formulation of the tax evasion and incentive disposition.

1. The formulation of the crime in the Criminal Code of Ukraine presupposes the presence of such a mandatory element as a deliberate action and ultimate goal. The existence of intent for the Spanish Criminal Code is not important; there is a sufficiently causal connection between actions or inaction and the occurrence of negative consequences in the form of ineligible funds to the budget.

2. Incentive rule in part 4 of Art. 212 of the Criminal Code of Ukraine provides for the possibility of exemption from criminal liability in the event of repayment of arrears. This rule applies to a person who is under investigation and has acquired procedural status in it. The Spanish Criminal Code, in contrast to one incentive, established in the Criminal Code of Ukraine, introduced two incentives: 1) limitation of the time for recognition of the fact of tax evasion and repayment before the signing of an act or commencement of criminal prosecution; and 2) the multiplicity of debt collection in case of bringing the debtor in court.

Therefore, under domestic law, on the one hand, law enforcement officers have an extremely difficult task of proving the intentional actions of the head to 
minimize tax obligations, and on the other hand, if the law enforcement agencies achieve a positive result, when the evidence gathered cannot be denied, the debt can be repaid at any stage before the court leaves the counselling room, and in this way, the person not only avoids criminal liability but also uses the debt throughout the time of the proceedings is conducted that lasts for years.

Such conditions make it difficult to encourage the taxpayer to behave properly, as opposed to Spain, where the payer is always in a position to: make a timely recognition of the fact of tax evasion and reimbursement, without any legal consequences for himself or on the basis of competition, to prove that all business transactions are conducted in compliance with the law, and in case of uncertainty - to be punished in the amount that reaches 600 percent of the amount of debt. In this case, the personal attitude of the payer to minimize tax, awareness of the conditions and procedure of taxation, etc., is not essential for the decision of the court to make a decision.

A slightly different approach is demonstrated in the laws of the Federal Republic of Germany and the United States, where criminal liability comes only from the facts of intentional tax evasion. Non-payment of taxes by negligence, including due to lack of knowledge of the payer regarding the need for payment, excludes criminal liability. However, the application of such an approach is offset by the fact that the existence of intentions is not so much about its availability for the commission of specific actions, business operations, facilities that can be established in case of detecting the fact of forgery of documents or providing false information and, first of all, by assessing the value of property, the property of such a payer, the ability to lead a lifestyle for funds officially declared.

That is, one of the main means of proving the taxpayer's guilt in these countries is the use of indirect methods that only capture the fact of the mismatch of the property status with the declared profits and this is sufficient for the conclusion of the intention to avoid tax (http://www.stattionline.org.ua/histori/113/21088rozsliduvannya-uxilennya-vid-splati-podatkiv-dosvidfrn-ta-ssha.html).

Thus, it can be concluded that the formal definition of tax evasion as intentional acts in Ukraine coincides with the definition in Germany and the United States, in contrast to Spain, where criminal acts are considered to be any act that results in harm to the budget through non-receipt of funds. However, in content, unlike Ukraine, where the prosecution is inclined to commit concrete actions, forcing the responsibility for tax evasion in the US, the Federal Republic of Germany, and Spain intent most often due to the inconsistency of the general property status with declared income and the dubiousness of transactions.
In this case, in the tax legislation of the United States and other developed countries, the presumption of innocence, in tax cases, proving the right to rely on the taxpayer and the latter is deprived of the opportunity to refuse to provide information that may be used against him during the trial.

At the same time, although the USA legislation criminalized not only non-payment of taxes, even actions aimed at attempting to evade taxation, the very procedure for collecting tax arrears also prompts the payer to cooperate.

The main purpose of tax authorities is precisely the filling of the budget and not the bringing of the person to liability.

This approach is implemented by the implementers of the order, in which the taxpayer repeatedly sends claims for payment of taxes, which he can appeal to a tax authority or to a court. Subsequently, the property of such a taxpayer is arrested, which can be cancelled before the start of tenders in the event of repayment of arrears. At the same time, payment of arrears with additional payments on it excludes prosecution and bringing a person to criminal liability.

Although unlike Spain's legislation, such incentive mechanisms for debt repayment as timeliness of such actions and the multiplicity of foreclosure are not applied, the same goal is achieved by arresting the property and selling it quickly if the debtor delays.

A significant difference is also in the mechanisms of counteracting fictitious entrepreneurship.

For example, according to the legislation of the Republic of Belarus, the use of fake enterprises is criminalized by establishing responsibility for:

1. Purchase of goods by non-cash payment from fictitious enterprises with subsequent realization for cash.

2. Acquisition of goods for cash through a parent company at a price lower than sold for a few percent and their subsequent sale.

3. Purchase of goods at the minimum price and further realization of their fictitious enterprise.

Thus, the legislator of the Republic of Belarus, by criminalizing the aforementioned economic relations, directed efforts to establish criminal liability, first of all, not for the creation of a fictitious enterprise but for the use of his "services", the task of such activity of losses, which is a real social danger.

Spanish criminal law (articles 290, 293, 294, 295) provides for the responsibility of the leaders of associations (actual or legal) for the formation of associations when they falsify annual and other documents that must reflect the legal or economic situation of the organization, which may contribute to the cause of economic harm to the association itself, its members or third parties (Article 290 of the Criminal Code of Spain) (Criminal Code of Spain, 1998).

Fictitious entrepreneurship is seen as a form of fraud in France, Greece, the PRC, Italy, Germany, Switzerland, 
the United Kingdom, the United States, Canada, as the main means of committing it is deception and abuse of trust (Baturina, 2011).

It is precisely the fact that managers of enterprises in the real sector of the economy are responsible for using the services of a fictitious enterprise can ensure the receipt of funds to the budget, in contrast to the massive prosecution of innocent people who are deprived of funds even in their existence.

Another stimulus to the detection and suppression of fictitious business is also the encouragement to cooperate in identifying fictitious enterprises in banks and other financial institutions.

In particular, the US law requires financial institutions to detect suspicious transactions and report them to law enforcement agencies. For failure to comply with these requirements, financial institutions and their officials may be liable to civil and criminal liability in the form of fines that exceed the sum of a suspicious transaction in a multiple amount.

In this case, signs of such suspicious transactions amounting to more than 10 thousand US dollars, a noneconomic operation, and any transactions that may be very useful in illegal activities are identified (Osika, 2003).

It should also be noted that there are problems in distinguishing the lawful optimization of tax liabilities or tax evasion and tax evasion as unlawful activities to reduce deductions to the budget.

In domestic legislation, this issue remains unresolved; however, the USA has significant advances in this area. Legal dictionaries interpret the avoidance of taxation as the use by a person of tax planning opportunities permitted by law to reduce fiscal obligations. As Justice Court Judge 2 of the District John J. Hend has rightly observed, "nobody, in fulfilling his public duty, to pay more than the law requires, since taxes are a forced deduction, not voluntary contributions."

However, the wording of Art. 212 of the Criminal Code of Ukraine, as well as Paragraph 7201 of the PC of the United States, do not contain indications as to the unlawfulness of the actions of the subject aimed at minimizing (optimizing) tax liabilities that blurs the boundaries between lawful conduct for the optimization of activities and unlawful tax evasion (The Criminal Code of Ukraine, 2001).

Legal uncertainty in domestic legislation between the possible legitimate conduct of the taxpayer to minimize payments is also one of the negative factors in the field of taxation.

\section{Practical application of the results}

Criminal legislation needs to be amended as regards the formulation of the disposition of Articles 212 and 205 of the Criminal Code of Ukraine, as well as the introduction of incentive rules for the lawful conduct of taxpayers and financial institutions.
In particular, from the disposition of Art. 212 of the Criminal Code of Ukraine, it is expedient to exclude such a sign as "intentional" by establishing liability for any actions, contrary to the requirements of tax legislation, which led to non-receipt of taxes and mandatory payments to the budget.

It is necessary to establish an incentive rule for the absence of grounds for criminal prosecution in the event of payment of tax and funds for its untimely transfer until the commencement of criminal proceedings or the signing of a tax audit act.

It is also desirable to implement in Art. 212 of the Criminal Code of Ukraine, stimulating the norm regarding the use of multiplicity in the event of blaming the plain in court.

Disposition of Art. 205 of the Criminal Code of Ukraine should be formulated in such a way that the criminal responsibility came only for the use of "services" of fictitious enterprises and not for the fact of their formation. In this case, the actions of those who created, acquired, or accompanied the establishment, the acquisition of the enterprise qualify as incitement or aiding in the use of a fictitious enterprise or as an aiding in evasion of taxes and establish criminal liability for late notification or failure to report suspicious banking transactions by financial enterprises the sector.

The above proposals for changes to the legislation on criminal liability and tax legislation will have a positive impact on solving urgent problems in the field of public relations and will facilitate law enforcement and other state bodies in filling the budget and ensuring economic security throughout the country.

\section{Conclusions}

Thus, we can conclude that the criminal law means of influencing economic relations in Ukraine in the field of taxation are ineffective; their application does not ensure the proper economic security of the country. The complexity of eliminating the consequences of making fictitious business determines the need to concentrate efforts on preventive activities in this area, the timely detection and cessation of such activities, and the involvement in identifying questionable financial transactions of financial sector enterprises. The low effectiveness of the judicial practice of tax evasion and false entrepreneurship creates an impersonal perception of criminal behaviour and does not fulfil regulatory, punitive, and preventive functions.

Thus, in addition to developing effective methods of implementing economic policies both in the country and abroad, in many respects the resolution of problem issues aimed at achieving the stability of the economic situation depends on the timely perception and reproduction by the legislator in the normative material of the trends that are taking place today the world, especially in the field of such dynamic in nature of social relations. 


\section{References:}

Electronic resource. Retrieved from: http://zakon4.rada.gov.ua/laws/show/4025-17

Electronic resource. Retrieved from: http://reyestr.court.gov.ua/Review/72367032

Electronic resource. Retrieved from: http://www.reyestr.court.gov.ua/Page/2

Electronic resource. Retrieved from: https://juscutum.com/futbolisti-vs-podatkivci-ofshorne-merezh/

Criminal Code of Spain (1998). [ed. and with the prelude N.F. Kuznetsova, F.M. Reshetnikova; per. V.P. Zyryanov, L.G. Schneider]. M.: Mirror, 218 p.

Electronic resource. Retrieved from: artlibrary2007.narod.ru/kodeks/ispanii_uk.doc

Electronic resource. Retrieved from: http://www.stattionline.org.ua/histori/113/21088-rozsliduvannyauxilennya-vid-splati-podatkiv-dosvid-frn-ta-ssha.html

Baturina E.V., Litvinenko A.N. (2011). Fictitious entrepreneurship: the problem of non-compliance of economic and legal regulation with real economic practice. Bulletin of the St. Petersburg University of the Ministry of Internal Affairs of Russia. St. Petersburg, No 4(52), p. 100-105.

Osika I.M. (2003). Counteraction of economic crime: review of international sciences.-pract. Seed. Right and Safety. T. 2, No. 2, p. 213-219.

Electronic resource. Retrieved from: http://www.big-lib.com/book/63 Kriminalnii_kodeks_Ykraini 10 rokiv_ochikyvan/6786_vidmejyvannya_podatkovoi_optimizacii_vid_yhilennya_vid_splati_podatkiv federaTnii_dosvid_ssha

Electronic resource. Retrieved from: http://elar.naiau.kiev.ua/bitstream/123456789/1006/1/mikish_dis.pdf 